\title{
A IMIGRAÇÃO JAPONESA DO PASSADO E A IMIGRAÇÃO INVERSA, QUESTÃO GÊNERO E GERAÇÕES NA ECONOMIA
}

\author{
THE JAPANESE IMMIGRATION FROM THE PAST AND THE INVERSE \\ IMMIGRATION, GENDER AND GENERATIONS ISSUES IN THE ECONOMY OF \\ BRAZIL AND JAPAN
}

\author{
Verônica Braga Birello ${ }^{1}$ \\ Patrícia Lessa ${ }^{2}$
}

\begin{abstract}
Resumo
$\mathrm{O}$ artigo tem por fim estudar as relações imigratórias japonesas. Os motivos históricos que levaram a referida situação no passado. Também o fenômeno da imigração inversa que por sua vez atingiu a população de japoneses nascidos no Brasil, sua causa e aspectos das várias etapas como saída do Brasil, trabalho no Japão e retorno ao país também serão abordados no corpo do texto. Levando em consideração as comemorações do centenário de imigração japonesa e a lacuna ainda existente nessa área da historia, economia e cultura o objetivo maior do projeto será avaliar a condição da mulher nesse processo de inclusão econômica e cultural que teve inicio em 1908 e na década de 1980 foi retomado. A imigração japonesa vista por diferentes mulheres japonesas de três gerações que serão entrevistadas e estudadas pela analise de conteúdo tendo como fundamento teórico os Estudos de Gênero.
\end{abstract}

Palavras-chave: Mulheres; Japão; Gerações.

\begin{abstract}
The article has the objective of studying the Japanese immigration relations and the historical reasons that led to immigration in the past. It also discusses the phenomenon of inverse immigration, which affected the population of Japanese who were born in Brazil. Considering the centennial commemoration of Japanese immigration and the gap that exists in this historical, economic and cultural area.The main objective of this article is to evaluate the woman's condition in this economic and cultural process of inclusion, which started in 1908 and restarted in the 80's. The Japanese immigration in the viewpoint of different Japanese women, from three generations, who were interviewed and studied for analysis of content, having as theoretical basis the Genders Studies.
\end{abstract}

Keywords: Women; Japan; Generation.

\footnotetext{
${ }^{1}$ Acadêmica do curso de Secretariado Trilíngue da Universidade Estadual de Maringá (UEM), participante do Grupo de Pesquisa sobre Pedagogias do Corpo e da Sexualidade (GEPECOS/UEM). E-mail: ve_mione@ @otmail.com;

${ }^{2}$ Graduada em Educação Física na Universidade Federal de Pelotas, Mestre em Filosofia, Doutora em Historia. Professora da Universidade Estadual de Maringá, Membro do GEPECOS.
} 


\section{Introdução: um estudo de gênero na cultura nippo-brasileira}

Há uma lacuna a ser preenchida quando se trata de imigração japonesa, que aumenta quando falamos das mulheres japonesas que imigraram para o país. É necessário pesquisar vários aspectos que as envolvem. O papel das mulheres na imigração para o Brasil, sua permanência, cotidiano que provavelmente se alterou, e em quais aspectos isso se deu. Em que influíram na cultura brasileira ou foram influídos por ela?

Temos de ter em mente que na época da imigração o casamento entre brasileiros e japoneses era totalmente proibido pelas famílias japonesas. Muitas mulheres imigraram para o Brasil com casamentos arranjados, não conheciam os noivos e vieram para o país com a obrigação de casar com os imigrantes pós-guerra que também eram rejeitados pelas famílias japonesas que já estavam no país. Portanto, diversos motivos fizeram com que as mulheres viessem para o Brasil, além da mudança das famílias. Mas entender o seu papel aqui no Brasil é o principal para essa pesquisa.

Outro importante aspecto é o fenômeno imigratório que vem acontecendo desde a década de 80 com a chamada "imigração inversa", ou seja, a ida para o Japão dos brasileiros descendentes de japoneses, os chamados nikkeis. Entender o motivo do êxodo do país de origem para o país dos antepassados e a situação que elas enfrentam ao chegar em um país estrangeiro e posteriormente o regresso ao Brasil é fundamental para entendermos o motivo pelo qual algumas não conseguem se readaptar a vida no Brasil.

A inserção econômica das mulheres, que saem do país muitas vezes sem renda financeira que proporcionaria a auto-sustentação, em uma economia na qual tem trabalho garantido e adquirem independência financeira é também um fenômeno a ser estudado em duas partes. A primeira parte é como elas passam a administrar esse rendimento, pessoal ou familiar. E o que muda quando regressam ao Brasil. Muitas perdem essa autonomia, como acontece a readaptação a situação antiga na administração das finanças.

Todos esses pontos apresentados constituem uma questão gênero econômica na qual a mulher influiu e influi em épocas diferentes e em paises distintos, mas que se correlacionam devido a um acontecimento histórico a imigração japonesa.

Muitas das tradições do Japão foram preservadas pelos que aqui chegaram e elas perpetuaram através das gerações, tanto é que até hoje muitas crianças aprendem o japonês desde pequenas. Outros costumes foram adotados por alguns ocidentais, é o caso da religião ou da filosofia de vida oriental, cada vez mais vemos adeptos que não tem nenhuma 


\section{DIVERS@!}

Birello e Lessa

descendência. De várias formas podemos dizer que os japoneses preservaram sua cultura e foram influenciados pela forma de viver brasileira. Os festivais japoneses realizados até hoje são outra prova disso, cada vez mais atrai o público não oriental atraídos por música, dança, culinária e outros.

Os 100 anos de imigração japonesa serão comemorados em grandiosas festas por todo o país, principalmente na área de São Paulo e Paraná onde se encontram a maioria dos descendentes. A família imperial visitará várias cidades do país inclusive Maringá. Aqui temos uma grande colônia que oferece margem para grandes e diversas pesquisas de campo. É muito importante para a região e país o desenvolvimento desse tipo de pesquisa que se relacione a realidade encontrada pelos habitantes da cidade, sua história e experiências de vida.

Esta pesquisa justifica-se porque a imigração em caráter geral é amplamente estudada já que nosso país contou com a vinda de vários povos em diferentes períodos históricos para formar uma nação, entretanto a imigração japonesa não foi alvo até o momento de uma grande quantidade de pesquisas que a analisasse, principalmente no tocante as mulheres japonesas. Em 2008 o Brasil comemorará o centenário da vinda desse povo de um país e de uma cultura tão distante e distinta da nossa. Esse motivo vem agregar importância a pesquisa que será realizada.

O primeiro objetivo é compreender o período e situação histórica das imigrações para o Brasil e para o Japão através do levantamento bibliográfico; como também analisar o discurso de três gerações de mulheres japonesas, buscando entender suas relações com a cultura oriental e ocidental.

Nossa metodologia foi dividida em duas partes. A teórica através do levantamento bibliográfico de teses, artigos, livros e materiais disponíveis na Internet. A segunda parte é prática do tipo pesquisa de campo. O instrumento para coleta de dados foi entrevistas semiestruturada com a população definida de três mulheres de três gerações japonesas, a primeira imigrante nascida no Japão, as outras duas nascidas no Brasil que realizaram a imigração inversa, todas de uma mesma família.

\section{Gênero e cultura Nipo-brasileira: Do Japão para o Brasil, a chegada de um povo}

No Brasil a migração japonesa teve inicio em 18 de junho de 1908 e se acentuou no período do pós-guerra. Esses imigrantes encontraram grandes dificuldades e situações 
inesperadas. Vieram para substituir mão-de-obra escrava e tinham esperanças de enriquecer e voltar para o seu país.Aqui enfrentaram grande preconceito. Viviam nas chamadas colônias, mas não caracterizavam um grupo homogêneo, embora muitos pensem assim.

A pesquisadora Célia Sakurai explica muito bem em seus textos que os japoneses imigrantes de antes do período pós-guerra não aceitaram a vinda dos imigrantes do pós-guerra o que causou grande hostilidade entre eles. Os chamados: "Japão-novo" (imigrantes do pósguerra) tinham maior nível de escolaridade que os seus antecessores e os tratavam como inferiores por isso. Também alegavam que esses tinham abandonado o país quando mais precisavam e não tinham vivido a guerra em sua terra. Já os imigrantes que aqui estavam acusavam os "Japão-novo" de aproveitadores, pois, encontraram já pronta a boa imagem dos japoneses aqui, eles tinham conseguido todo o respeito, trabalhando duro e eles chegavam se apropriando de suas conquistas

Ao se falar das mulheres, elas vieram para o Brasil seguindo seus familiares e maridos. Podemos observar na Tabela 1 que vieram tantas mulheres quanto homens, as porcentagens não variam $10 \%$ :

Tabela 1. Imigrantes japoneses - distribuição por sexo 1908-1945

\begin{tabular}{l|l|l}
\hline \multicolumn{1}{c|}{ SEXO } & \multicolumn{1}{c}{ FREQÜÊNCIA } & PORCENTAGEM \\
\hline Masculino & 100918 & 55,2 \\
Feminino & 81803 & 44,8 \\
Total & 182721 & 100,0 \\
\hline
\end{tabular}

Fonte: SAKURAI, Célia ( 2004,p.7) Apud SUZUKI (1964)

Dentro das colônias, tanto as mantidas pelo governo japonês quanto as criadas involuntariamente, essas mulheres imigrantes educavam suas crianças falando não a língua do novo país e sim a sua língua materna. Isso muito se deve ao pensamento de retorno ao Japão quando melhorassem de vida. O português que aprenderam era apenas funcional não teria grande importância uma vez que voltassem. Dentro dessas colônias eram pouquíssimos brasileiros, os japoneses não procuravam a mistura de etnias e, portanto, não eram vistos com bons olhos pelo governo e pelo restante da população do país. Assim raramente uma jovem japonesa se casaria com um brasileiro não descendente. Dentro desse aspecto matrimonial houve grande tensão com a chegada dos imigrantes do período pós-guerra. A família das jovens que já estavam no país viam como uma vergonha se suas filhas casassem com esses "Japão-novos" e impediram essas uniões por muito tempo, mesmo esses tendo melhores 
condições financeiras que os outros. Foi nessa época que no Brasil se praticou os chamados “casamentos por fotografias". Era uma prática bastante utilizada no passado pelos imigrantes que foram para os Estados Unidos conhecida então como "Picture brides". As mulheres não tinham escolha a não ser seguir o que era ditado pela família. Eles trocavam fotos entre Brasil e Japão e o casamento era "negociado" por intermediários. Os noivos não se conheciam e mais de 400 jovens japonesas migraram para o Brasil com a finalidade de serem desposadas por esses japoneses que vieram tentar uma vida melhor no Brasil. Elas eram conhecidas como hana yume que literalmente quer dizer "flor do sonho".

Muitas dessas situações aconteceram devido às bases culturais dos japoneses. A antropóloga norte-americana Liza Dalby em seu livro "Gueixa" mostra a sociedade japonesa como sendo fundamentada no patriarcado.

Os homens japoneses estão acostumados a serem servidos pelas mulheres.Essa não é a única forma de interação homem/mulher no Japão, mas os japoneses do sexo masculino a acham perfeitamente natural. $\mathrm{O}$ estilo cultural da masculinidade no Japão tende a exigir a subserviência da mulher (ao menos pro forma) e muitas coisas contribuem para uma ideologia na qual os homens são a fonte da autoridade (DALBY, 2003, p.32).

Mesmo com essa característica, a crítica feminista, ao analisar essa sociedade não deve convergir para uma generalização que contrarie essa cultura focada no dominante patriarcal. Se isso acontecesse seria recair em uma metanarrativa, a do "patriarcado". Essa idéia contra os discursos de massa (metanarrativa) que é defendida no texto de Linda Hutcheon chamado "A incredulidade a respeito das metanarrativas: articulando pós-modernismo e feminismos", também se aplica nos estudos da cultura nipônica, pois, a tende-se a vê-los como sociedade homogênea. Como Hutcheon diz: “[...] os feminismos têm focalizado especificamente o sujeito feminino da representação e tem começado a sugerir modos de desafiar e mudar estas formas dominantes, nas várias dimensões da cultura [...]" (HUTCHEON, 1993, p. 22). Isso mostra que as praticas sociais deveriam ser mudadas como um todo e não apenas o patriarcado que é a mais evidente no Japão.

A língua, a religião, culinária, cerimônia do chá, arranjo de flores são apenas alguns exemplos da tradição oriental que foi preservada em nosso país tão diversificado. Entretanto, isso não foi por acaso. As mulheres tinham a função de manter a ordem da casa enquanto o marido trabalhava nas plantações de café ou em outras funções ligadas a agricultura, comercio, tinturaria... Essas mulheres ensinariam a língua cristalizada do começo ou metade 
do século XX aos seus filhos, dependendo do período de migração, essas crianças aprendiam o japonês antes do português. Essa característica além de interessante foi muito importante para a manutenção da cultura oriental dentro das colônias e perpetuação dos costumes no país receptor dos imigrantes. Como Elza Taeko Doi afirma em seu texto "O ensino do japonês no Brasil como língua de imigração":

\footnotetext{
...Os imigrantes de primeira geração são considerados falantes da língua materna e da língua do país receptor, tendo esta última uma função apenas instrumental na maioria dos casos; a segunda geração já seria bilíngüe nas duas línguas; e a terceira geração seria de falantes nativos da língua da sociedade majoritária, com pouca ou nenhuma competência na língua dos ancestrais (DOI, 2006, p.66-67).
}

Elza ao retomar Hammers \& Blanc, 2006, deixa claro que para os japoneses "core value" fator de preservação da cultura em terras estrangeiras é o idioma o que leva a busca de seu ensino. Para os japoneses falar em seu idioma de origem é quesito básico para não perderem a soberania de japoneses, não brasileiros. No inicio buscavam a formação de um "japonês" e seguiam o "Decreto Imperial sobre Educação", uma vez que visavam o retorno ao Japão e queriam os filhos inseridos dentro da sociedade nipônica. No período pós-guerra já não se educava para ser "japonês" embora, houvesse o desejo por parte dos pais e professores que se mantivesse o nihonjin no kokoro que seria um espírito japonês. Os descendentes tinham mais contato com brasileiros fora das colônias que dentro das comunidades causando um distanciamento e pouco uso da língua. Com as imigrações dos "japão-novos" uma revitalização dos professores aconteceu. As mulheres que vieram e se empregaram nas escolas dentro das colônias tinham não só mais conhecimento sobre a língua que os antepassados, mas também dominavam as evoluções que se sucederam até o momento na terra natal. Porém, essa revitalização não garantiu a perpetuação da língua como outrora. No período mais recente com a guinada cientifica e tecnológica do Japão os pais viram na língua uma espécie de "futuro" para os filhos que possivelmente imigrariam para o Japão, por isso voltaram a matricular suas crianças em "escolinhas" de japonês que muitas crianças vão obrigadas. Outro fato que ajudou a volta do ensino do japonês como língua estrangeira foi o interesse de brasileiros não nikkeis pela língua e cultura oriental.

Verifica-se que o ensino do japonês passa a ter uma finalidade instrumental e pragmática, principalmente porque a procura pela língua se estende aos brasileiros não-descendentes de japoneses. 
O ensino de japonês como LE, assim proposto, visa, assim, atender ao público descendente que não usa o japonês em família e aos não nikkeis que não têm conhecimento da língua.

Com exceção de algumas escolas que desde os anos 70 já ofereciam cursos de japonês como LE4, muitas escolas particulares e/ou administradas pelas comunidades locais continuam ainda apegadas à tradição de ensino, tanto em termos de metodologia quanto em seus objetivos (Anais do 2o. Simpósio, 1981; e Anais do $4^{\circ}$. Simpósio, 1995, Apud DOI, 2006, p.73).

Não devemos esquecer-nos das religiões fundadas no Japão que vieram para o Brasil e continuam a serem difundidas, praticadas e a conseguir cada vez mais adeptos a crenças e tradições tipicamente da cultura japonesa. Atualmente é maior o número de não descendentes adeptos as crenças religiosas orientais e para cada 100 mulheres são 64 homens participantes segundo diz Andréa Tomita em As Novas Religiões Japonesas como instrumento de transmissão de cultura japonesa no Brasil em seu estudo sobre religiões e a perpetuação da cultura. A música também assume papel fundamental. Danças típicas como o bon odori, que se traduzida literalmente quer dizer "dança aos mortos" e outras manifestações artísticas mais conhecidas como os tambores que até hoje são populares dentro da sociedade nipo-brasileira e brasileira em geral que acompanha os diversos festivais, ou seja, festivais que se realizam no decorrer do ano pelo país.

\section{Do Brasil para o Japão: mulheres e a imigração inversa}

Abordamos, a partir, de agora um aspecto muito visível desde o final do século XX. Estaremos falando sobre a "imigração inversa", focalizando a mulher nikkei nessa jornada de volta ao país dos ancestrais. Como essa mulher brasileira é tratada por não ser mão-de-obra especializada e, ainda, por cima estrangeira em um país em que o preconceito ainda é muito forte quanto a estes e possui as bases culturais instauradas no patriarcado. Lúcia E. Yamamoto (2006, p.20) descreve sobre a participação da mulher no processo migratório e como isso é pouco discutido e pesquisado:

Os estudos relacionados à migração feminina são críticos quanto ao pouco caso que se faz da presença das mulheres no processo migratório. Mesmo os pesquisadores que apontam para a feminização desse processo, não dão a devida importância ao tema. Quando são consideradas neste movimento migratório, as mulheres são vistas como dependentes de familiares ou então somente dentro do papel que ocupam na 
esfera doméstica (KOFMAN, 1999). Neste sentido, a ênfase em termos de produção econômica faz com que as mulheres migrantes sejam ignoradas como agentes produtivos ou mesmo como participantes ativos na migração (CAMPANI, 1985; CASTLES e MILLER, 1993; STIER, 1991; ZLOTNIK, 1995).

Entre gêneros não há diferenças no motivo de imigrarem para o Japão. Ambos são motivados pelos melhores salários e a busca de conseguirem guardar dinheiro e voltarem para o Brasil em uma situação econômica melhor. A maioria se emprega com trabalhos temporários nas fabricas os conhecidos arubaitos, do alemão arbeiten (trabalho), arubaito é um trabalho temporário especialmente aos estudantes que investem o período de férias estudantis que não tem direitos trabalhistas ou outros benefícios a não ser as horas extras que garantem um bom rendimento mensal. Acrescenta-se ai a realidade que as mulheres ganham menos que os homens e teremos um panorama geral das condições dessas imigrantes.

Há mães que imigram deixando seus filhos com tios e avós. Elas, na maioria das vezes, acabam perdendo a infância dos filhos. Outras vão acompanhadas do marido e das crianças, o que acaba facilitando a adaptação.

As mulheres, mais que os homens enfrentam o dilema dos filhos, pois existe o laço "Brasil - Japão", isso quer dizer que no Japão ambos os pais trabalham durante o dia todo para sustentarem a casa e economizarem o que for possível. Assim os filhos ficam em casa o dia todo e sozinhos. Muitos não freqüentam as escolas japonesas, pois os pais sempre esperam voltar para o Brasil. Assim não teriam motivo estudarem no país, as crianças estudariam quando voltassem. Muitos também não freqüentam as escolas brasileiras, pois são muito caras. Segundo a professora Eunice Akemi Ishikawa da Universidade de Artes e Cultura de Shizuoka as mães tentam ajudar os filhos nos deveres de casa. Entretanto o japonês que elas falam é muito básico e misturado com dialetos das províncias de pais e avós, poucas sabem os ideogramas. Essas crianças muitas vezes sofrem discriminação por parte dos colegas e simplesmente deixam de freqüentar a escola. Os pais muitas vezes não o possuem conhecimento desses fatos ou não são capazes de mudar a situação.

Esses problemas são comuns e o governo japonês se preocupou de certa forma com esses estrangeiros, tanto que contratou várias profissionais tradutoras/orientadoras de idiomas para as crianças não proficientes em japonês. É uma função desempenhada por mulheres que visitam várias escolas públicas da província pela qual é contratada e ajuda as crianças com um reforço escolar. Yamamoto (2006) explica em seu texto que embora a maioria dessas contratadas tenham nível superior no Brasil todas elas são contratadas como mão-de-obra 


\section{DIVERS@!}

Birello e Lessa

desqualificada no Japão não passando de trabalhadoras temporárias também, sem direitos trabalhistas nenhum. Enquanto os educadores japoneses legítimos sempre recebem formação, cursos, workshops, essas mulheres não tem nenhum tipo de curso especifico para exercerem essa função, muitas foram indicadas ao cargo. Uma dificuldade freqüente por essa falta de instrução é a tradução dos boletins escolares, informativos e algumas matérias especificas. Isso se dá ao fato da escrita japonesa ser extremamente complicada. Há kanjis (ideogramas que representam palavras ou silabas, podem ter várias leituras dependendo de como está acompanhada) específicos para matérias como matemática, japonês, ciência, economia. Esses aspectos dificultam a tradução e o auxilio as crianças, mas elas não desistem dessa missão.

Entre alguns estudos de casos que Yamamoto (2006) apresenta em seu artigo intitulado "Desqualificação profissional: Nikkeis brasileiras no Japão", destaca-se o motivo pelo qual essas mulheres aceitam esse trabalho, mais uma vez o tempo para cuidar dos filhos foi apontado, pois geralmente a jornada de trabalho é menor que nas fábricas. E a satisfação de poder ajudar as crianças de alguma forma em um país estrangeiro. Essas mulheres conciliam seus papeis de profissionais, de mães e de esposas. A maioria, quando se fala do ponto de vista familiar está satisfeita. Mas ao analisar o ponto de vista profissional isso muda. Elas não estão se qualificando, o que complica a inserção no mundo de mão-de-obra especializada tanto no Japão, quanto no Brasil já que sonham com um retorno.

\section{Resultados e Discussões: três gerações de mulheres e suas experiências de vida}

Essas três mulheres entrevistadas, embora da mesma família, viveram muitas situações diferentes, a maioria delas condicionadas pela época e sociedade na qual estavam inseridas. A primeira entrevistada de 81 anos imigrou para o Brasil com a família na idade de 10 anos. Quando morava no Japão, na região de Hokaido, uma das mais frias do país, freqüentava a escola com os irmãos enquanto o pai cuidava do arrozal e sua mãe das plantações de verduras e animais ao redor da casa. Naquela época, no Japão quanto aqui, as mulheres não trabalhavam fora, por isso, sua mãe auxiliava o esposo na plantação enquanto todos os filhos iam a escola. Ela nos disse que teve muita sorte quando mudou para o Brasil, pois a colônia em que moravam era grande e tinha escola, como ela era a mais nova e tinha irmãos ela pode ir à escola enquanto os outros ajudavam o pai e a mãe no cafezal, por exemplo, o marido dela não teve a mesma sorte, teve de ir trabalhar bem cedo. Esse regime era semelhante ao que vigorava no Brasil da época. 


\section{DIVERS@!}

Birello e Lessa

A prática do casamento negociado por terceiros também foi presente na vida dessa senhora. Ao receber uma proposta de casamento, como ainda tinha dois irmãos mais velhos e solteiros, seu pai disse que só poderia casar-se depois dos irmãos. Estes casaram e então chegou à vez dela que nunca tinha visto o noivo em sua vida, e segundo ela tinha tanta vergonha de olhá-lo que só via os sapatos dele. Depois do casamento ela afirmou que os dois às vezes conversavam, mas que com o passar dos anos isso melhorou. Como foi a vida dessa imigrante? Bem, depois de casada ela morou com as duas cunhadas e sogra em uma mesma casa, faziam tudo junto enquanto os maridos trabalhavam na roça. Tinham de cozinhar, lavar, cuidar das crianças todas juntas. Quando compraram terras maiores precisavam de mão-deobra como pedreiros, carpinteiros, bóias-frias, e ela era a responsável por tudo dentro da casa, tinha de limpar, cuidar dos filhos e cozinhar para todos. Ela diz: "De manha 6 horas tem que fazer café, pros trabalhadores, 9:30 tem que ter pronto o almoço, 1 hora o café de novo depois 3 horas tem outro lanche tem de fazer lanche, então eu não tenho tempo pra lavar prato nem nada, ai eu mandei uma empregada lavar pratos, e eu ficava só cozinhando e cuidando das crianças e eu limpava casa". Durante o tempo de construção na fazenda que compraram ela passava todos os dias assim. Ela nunca descuidou da educação dos filhos que em casa falavam japonês e na escola que construíram na fazenda tinham aula de português e japonês, como ela mesma quando pequena. Ela diz que os mandou estudar em outra cidade quando terminaram a escola da fazenda, então o cunhado comprou uma casa na cidade de Rolândia (interior do norte do Paraná) e a sogra cuidava de todos os netos que iam pra escola. Nesta época as crianças só falavam o japonês em casa quando voltavam. Ela diz que foi uma "Mistura do que eu aprendi no Japão e do que aprendi aqui”.

Quando perguntei se ela havia voltado ao Japão ela me disse muito contente que voltou pra passear com o marido. Aponta que o que mais gostou no Japão quando foi passear foi ver as crianças pequenas levando as outras pra escola, ver que elas fazem tudo sozinhas e, bem feito. Ela afirma que: "Não precisa preocupar como Brasil que tem malandro que tem carro, moto que corre de mais, é tudo bem organizado eu gostei muito de ver". Mas quando perguntei sobre voltar mesmo pro Japão ela diz: "Só pra passear. Eu já vivi tanto no Brasil, eu já gosto do Brasil, mas o Japão... Eu nasci, estudei lá mas vontade de morar não, é um pais organizado bem bonito, tudo mundo estudado. Aqui no Brasil tem tudo, fartura...”. Ela cita todas as atividades que realiza aqui junto com as amigas do grupo da terceira idade, diz que vai à hidroginástica, e depois na ginástica, vai aos sábados no karaokê, no bingo, nas festas que são organizadas pela igreja budista. Diz que quando chove ela fica em casa ouvindo 
musicas ou vendo programas do Johnnys, mas que sempre assiste novelas e noticiários em português pra não esquecer. Ela mostra grande motivação mesmo após a morte do marido quando ela sofreu de depressão grave, segundo sua neta. Ela diz: "Eu ficar sozinha em casa não".

Quando passamos pra a próxima geração já temos um exemplo da real imigração inversa. Ela mudou-se com a família, esposo e filhos, para o Japão onde moraram por cinco anos, e retornaram há cinco anos também.

A partir do seu ponto de vista e experiências ela me respondeu: "A mulher já evoluiu bastante no Japão porque elas trabalham, mesmo as casadas, nas fabricas e tudo, mas ainda tem aquela certa... aquela submissão, não é como aqui, a mulher fala tudo que pensa, não tá nem ai, lá tem submissão. As senhoras de uma certa idade são independentes nem que for meio período elas trabalham elas tem o dinheiro delas. Lá o costume é assim o marido trabalha as mulheres guardam o dinheiro, mas depois tem que prestar conta de como gastaram esse dinheiro".

No Japão ela teve dois trabalhos, o primeiro em uma fabrica, e o segundo em uma escola, como professora, função que ela exercia antes no Brasil. Trabalhava numa escola brasileira, com filhos de imigrantes que não queriam seus filhos em escolas japonesas ou que não se adaptavam a escola japonesa, na maioria, de séries ginasiais como Lili Kawamura (2005, p. 66) comenta no artigo "O processo educativo dos brasileiros no Japão": "Embora a maioria das crianças das séries iniciais manifeste estar bem integrada, desejando permanecer neste país, as das séries finais e do curso ginasial expressam dificuldades de adaptação, desejando voltar ao país de origem". A autora observa um aspecto preocupante presente na parte japonesa e brasileira enquanto esteve lá:

Acho que faz parte da cultura, as crianças brincam, conversam, mas falta entrosamento entre pais e filhos, você percebe isso. Não sei se o Brasil é assim hoje também, tanta preocupação com trabalho esquece a parte afetiva, principalmente quando os filhos estão crescendo e precisam de atenção. Como os brasileiros que estão lá, não tem tempo pros filhos, eles querem que a escola resolva tudo porque eles pagam, e os filhos são rebeldes a escola tem que resolver um problema que começa desde antes (KAWAMURA, 2005, p. 66).

Quando ela trabalhava na fábrica as mulheres ganhavam menos que os homens. Ela conta que lá a questão do homem sustentar a casa ainda é muito forte, por isso, eles ganham mais. 
Ela lista os pontos positivos do Japão basicamente em organização e educação. Ela diz que nas repartições públicas todos são muito educados, mas que isso acontece porque moravam em uma cidade grande onde estavam acostumados com estrangeiros, se fosse interior a situação seria bem diferente, com muita discriminação segundo o relato de amigas que foram morar em cidades menores. Ela diz que a cultura do Japão modificou pequenos e importantes aspectos no convívio familiar e pessoal. Eles moravam em um condomínio da prefeitura e a maioria de seus vizinhos era de japoneses, lá as instruções de separação era toda escrita em kanjis o que dificultava a compreensão por isso levaram inúmeras repreensões e tiveram o lixo devolvido por não separar corretamente. Ela afirma continuar a separar o lixo aqui no Brasil: "E é tão simples, e eu acho que é uma coisa boa, pegamos o costume lá e voltamos assim". Ela diz que o costume do marido de entregar as finanças da casa pra mulher administrar eles também adotaram, mas com mais liberdade porque lá a mulher não vai ao banco, não faz depósitos, nada só o que o marido lhe entrega. Ela disse que lá o trânsito também é muito rigoroso, e hoje ela segue rigidamente as regras aqui no Brasil também.

Por outro lado ela diz que todos lá são muito exigentes, você tem de seguir as regras, de produzir, lá você não pode errar. Ela reclama bastante dos médicos por serem muito frios, mas afirma serem muito bem qualificados.

Embora ela goste do Japão, ela diz que prefere voltar só a passeio, pois tem uma vida, uma história no Brasil. Ela ressalta uma importante característica do Japão ao dizer: "Aqui você é japonês, você vai lá você é estrangeiro, a gente fica assim, sem saber, porque você é porque você tem cara, mas pra eles você não é. Você não se encaixa, não faz parte daquilo, você só está lá, mas não, não faz parte". É uma questão também abordada por Elisa Sasaki (2006) quando diz: “Os brasileiros que vão para o Japão deparam com uma realidade japonesa muito diferente da imagem idealizada do país passado por seus pais e avós imigrantes no Brasil” (SASAKI, 2006, p. 18). Assim como Sasaki (2006) cita no texto ela diz que se imagina uma coisa aqui no Brasil, mas quando se chega lá não é a maravilha que pensavam.

Passando agora para a terceira geração que agora com 23 anos temos uma visão um pouco diferente. Ela estudou em uma escola japonesa e diz não haver preconceito entre meninas e meninos, mas quanto ao fator estrangeiro. Quando pergunto sobre a visão japonesa da mulher, se existe algum preconceito ela me responde: "Eu acho que lá ainda tem bastante, mulher tem q cuidar das coisas de casa, estudar só pra ter o diploma e depois ficar em casa pra cuidar dos filhos e marido, mas tá mudando hoje tem mulher solteira lá porque quer ser independente, mas tem outras famílias que são diferentes que as mulheres trabalham, está 
mudando. Em relação a namoro é diferente, porque elas namoravam meninos na escola, mas ninguém sabia que eram namorados se não te contassem, sem nenhuma demonstração em público, era muito difícil um casal demonstrar que era casal, não como aqui. Mas em relação marido mulher é bastante machista lá, pelo que eu vi. Mulher que é independente, bem sucedida profissionalmente não é muito bem vista".

Ela diz que muitas mulheres fazem faculdade em busca de encontrar um marido bem sucedido lá dentro. Muitas vezes a relação dentro de casa é assim: "Você mulher fica dentro de casa, mesmo que você trabalha fora você faz os serviços de casa, não vamos dividir". Ela disse que percebe algumas mudanças, mas que a sociedade japonesa ainda precisa mudar muito pra que as mulheres alcancem os mesmo direitos que os homens.

Ela também ressalta a diferença salarial onde trabalhou uma distribuidora de frutas, onde as brasileiras trabalhavam em um setor separado dos japoneses e ganhavam menos por serem mulheres. Ela diz que lá a diferença era de gênero basicamente, não por serem estrangeiras.

Sobre costumes adquiridos ela diz que alguns foram temporários, que lá você faz pra não ser mal visto, mal educado, como se inclinar pra cumprimentar alguém, agora ela faz, mas menos, ela diz que o costume de separar o lixo ela também adquiriu lá, o de trocar os sapatos quando chega em casa e mudar ainda se vai pra fora no quintal, que isso ela mudou por agir assim lá. Ela diz que costumes triviais como rir batendo palmas ou falar tampando um pouco a boca são coisas que ela se vê fazendo inconscientemente. Mas diz que nas relações pessoais, em que os japoneses são bem mais fechados, isso ela não mudou porque convivia com brasileiros também.

Lá é muito diferente, ela acredita que no Japão, todos tem condições de sobreviver dignamente, de trabalhar, não é como aqui que muitos não conseguem emprego. Ela reclama do clima e da comida, diz que o verão e a comida do Brasil são maravilhosos. Ela demonstra muita vontade de voltar ao Japão, mas diz que não sabe se gostaria de morar lá ou não, se fosse pra analisar com a perspectiva que tinha enquanto viveu lá ela diz que sem dúvidas voltaria ao Japão definitivamente. Mas diz que precisa voltar pra saber, porque hoje a visão dela pode ser diferente da que tinha. 


\section{Considerações finais}

Muitas coisas parecem ter sofrido alterações desde a vinda dos imigrantes japoneses, tanto no Brasil quanto no Japão. Hoje quando as mulheres vão pro Japão, com a família ou não, elas se encontram em meio a uma sociedade ainda firmada no patriarcado, na qual são mal vistas e interpretadas caso tenham atitudes não submissas ou atitudes consideradas liberais. Contudo as mulheres brasileiras se vêem independentes economicamente e com trabalho garantido na maioria das regiões e épocas do ano. É agora que a mulher passa a influir na economia, surge um mercado consumidor diferenciado, mulheres estrangeiras, trabalhadoras residentes em outro país. Embora tentem guardar boa parte do dinheiro que ganham seus novos costumes prevalecem na administração do rendimento. As mulheres economicamente ativas no Japão aumentam e se transformam com a vinda das imigrantes brasileiras.

Todas essas mulheres tiveram a vida alterada, mas não se arrependem da mudança. Todas cresceram pessoalmente e aumentaram a capacidade de entender o próximo, o diferente.

\section{Referências}

DALBY, L. Gueixa. Rio de Janeiro: Editora Objetiva, 2003.

DOI, E. T. O ensino de japonês no Brasil como língua de imigração. Estudos Lingüísticos XXXV, p.66-75, 2006.

HUTCHEON, L. A incredulidade a respeito das metanarrativas: articulando pós-modernismo e feminismos. Revista Estudos Feministas, v. 1, n. 1, p.7-31, jan/jun 1993.

KAWAMURA, L. K. O processo educativo dos brasileiros no Japão. Pro-Posições, v.6, n. 2, p. 64-68, Jun. 1995.

\section{SAKURAI, C. Tensões dentro de um mesmo grupo: os japoneses do pós-guerra e os} antigos imigrantes. Disponível em: 


\section{DIVERS@!}

$<$ http://www.abep.nepo.unicamp.br/site_eventos_abep/PDF/ABEP2004 599.pdf $>$. Acesso em $04 / 12 / 07$

TOMITA, A. G. S. As Novas Religiões Japonesas como instrumento de transmissão de cultura japonesa no Brasil. Revista de Estudos da Religião, n 3, p. 88-102, 2004.

YAMAMOTO, L. E. Desqualificação profissional: Nikkeis brasileiras no Japão. Revista do Departamento de Geografia. São Paulo: USP, n. 18, p. 16-27, 2006.

SASAKI, E. A imigração para o Japão. Estudos Avançados, São Paulo: USP, v. 20, n. 57, Maio/Ago., 2006. 